\title{
Distributions of Polycyclic Aromatic Hydrocarbons in Coal in China
}

\author{
Bo Gao ${ }^{1}$, Qiyan Feng ${ }^{1,2 *}$, Lai Zhou ${ }^{1}$, Hongwei Wu ${ }^{1}$, Easar Alam ${ }^{1}$ \\ ${ }^{1}$ School of Environmental Science and Spatial Informatics, China University of Mining and Technology, Xuzhou, China
} ${ }^{2}$ Low Carbon Energy Institute, China University of Mining and Technology, Xuzhou, China

Received: 28 January 2018

Accepted: 11 April 2018

\begin{abstract}
Groundwater level rises rapidly when mine drainage systems stop functioning after mine closures. Free-form polycyclic aromatic hydrocarbons (PAHs) in residual pillaring and abandoned mining levels could continue to migrate because of eluviation leaching. Moreover, other aquifers are polluted with mine water through mining-induced fractures, faults, and poorly sealed drill holes. Therefore, the distributions of 16-PAHs in raw coal mined in China and the factors influencing these distributions were analyzed to assist mine closures. The results showed that the average concentration of PAHs was $10.540 \pm 7.973 \mu \mathrm{g} / \mathrm{g}$ in the raw coal samples, and PAHs with low molecular weights had the highest abundances, accounting for $44 \%$ of the total PAH concentration obtained. The highest concentration of 16-PAHs was observed in bituminous coals, followed by that in lignite, and the lowest is anthracite. The influence factors analysis reveals that carbon content, volatile matter, $\mathrm{H} / \mathrm{C}$, and $\mathrm{O} / \mathrm{C}$ have a significant effect on PAH content in raw coals. The volatile matter and molar ratio of $\mathrm{H} / \mathrm{C}$ play a leading role in the changing process in 16 PAHs, accounting for more than $60 \%$ of the total contribution.
\end{abstract}

Keywords: raw coal, polycyclic aromatic hydrocarbons, distribution, influence factor, degree of contribution

\section{Introduction}

As China's main energy source, coal production and consumption account for $72 \%$ and $62 \%$, respectively, of primary energy. The total output of raw coal was 3.41 billion tonnes (t) in 2016, down $9.0 \%$ from the same period a year earlier, and about $90 \%$ of coal comes from underground mines. In recent years, many coal mines have been closed because of the depletion of coal resources, resource integration, and coal mine

*e-mail: fqycumt@126.com production safety. Consequently, groundwater levels in these mines rise rapidly after the mine drainage systems stop working. Moreover, other aquifers are polluted with mine water through mining-induced fractures, faults, and poorly sealed drill holes. In northern China, the Ordovician or Cambrian aquifer, which is the main coal seam floor, is an important water source [1]. This water resource is at risk of being polluted when the groundwater above becomes polluted. For example, due to the influence of the coal mine water in Zibo mining area of Shandong Province, and Yangquan mining area in Shanxi Province, the karst groundwater has been polluted in different degrees [2-3]. Investigations show that around $40 \%$ of total groundwater in northern China 
has been being affected by different mining activities [1]. Groundwater pollution in the abandoned mining areas, i.e., heavy metals [4], inorganic pollution [5], and organic pollution [6], is affected by chemical, biological, and physical factors [7]. Therefore, Polycyclic aromatic hydrocarbons (PAHs) are among the most common and typical organic pollutants and thus receive substantial attention from fields that investigate environmental pollution in mine areas.

A persistent organic pollutant, $\mathrm{PAH}$ is a hydrocarbon composed of two or more aromatic rings. At the start of the last century, PAH was initially a widespread concern because it causes skin cancer in coke production workers [8]. Industrial processes such as pyrogenesis or combustion of fossil fuels (coal and oil) or biomass, and oil spills are the main sources of PAHs. Moreover, natural factors such as forest fires and volcanic activities can also produce PAHs [9-11]. The release of PAHs during pyrolysis is greatly dependent on pyrolysis temperature, gas/coal ratio, and coal quality [12]. Most PAHs generated by human activities are discharged in gaseous form, but eventually turn into solid form or attach to particulate matter. PAHs not only pollute water and soil by precipitation and settlement but also threaten human health through the food chain [13-15]. Moreover, most PAHs can cause cancer, abnormality, and mutation, and thus organisms exposed to PAHs for a long time are endangered [16-18]. A survey result indicated that lung cancer mortality increases by $5 \%$ in areas where benzo [a] pyrene concentration increases to $0.001 \mu \mathrm{g} /$ $\mathrm{m}^{3}$ [19]. At present, research on PAHs has been mainly focused on the following three areas: (i) the sources and distributions of PAHs in the environment, i.e., especially in the atmosphere [20-23]; (ii) the geochemical processes of PAHs in soils and sediments, including degradation, adsorption, and migration [24-27]; and (iii) the toxicity and risk assessment of PAHs in different environments [28-30].

Raw coals are generated from plant materials through a series of coalification under certain temperatures and pressures. In the Chinese Classification of Coals (GB/T 5751-2009), the raw coals are divided according to degree of coalification into lignite, bituminous, and anthracite coal, out of which the coalification degree of lignite is lowest, and of anthracite the highest. The main structural unit of coal is aromatic. The aromatic compounds in coal exist in two forms, namely macromolecular aromatic compounds, which



Fig. 1. Location of the sample sites in China. 
Table 1. Industrial analysis and elemental analysis of raw coal.

\begin{tabular}{|c|c|c|c|c|c|c|c|c|c|c|}
\hline \multirow{2}{*}{ Number } & \multirow{2}{*}{ Coal Mine } & \multicolumn{4}{|c|}{ Industrial Analysis (\%) } & \multicolumn{5}{|c|}{ Elemental Analysis (\%) } \\
\hline & & $\mathrm{M}_{\mathrm{ad}}$ & $A_{d}$ & $\mathrm{~V}_{\mathrm{daf}}$ & $\mathrm{FC}_{\mathrm{d}}$ & $\mathrm{O}$ & $\mathrm{C}$ & $\mathrm{H}$ & $\mathrm{N}$ & $\mathrm{P}$ \\
\hline $\mathrm{C} 1$ & Zhun Dong ${ }^{\mathrm{b}}$ & 13.32 & 9.48 & 29.68 & 63.65 & 15.17 & 80.31 & 3.42 & 0.68 & 0.00 \\
\hline $\mathrm{C} 2$ & $\mathrm{Ha} \mathrm{Mi}^{\mathrm{a}}$ & 16.58 & 9.09 & 40.69 & 53.92 & 20.28 & 75.00 & 3.61 & 0.82 & 0.00 \\
\hline $\mathrm{C} 3$ & Zha Lainuoer $^{\mathrm{a}}$ & 17.44 & 19.21 & 43.18 & 45.91 & 22.73 & 72.68 & 3.30 & 0.99 & 0.01 \\
\hline $\mathrm{C} 4$ & Bai Yinhua $^{a}$ & 9.90 & 12.32 & 45.04 & 48.19 & 20.61 & 71.90 & 4.89 & 1.58 & 0.00 \\
\hline $\mathrm{C} 5$ & Shi Getai ${ }^{\mathrm{b}}$ & 10.62 & 5.42 & 33.85 & 62.56 & 14.23 & 80.41 & 4.19 & 0.90 & 0.00 \\
\hline C6 & $\mathrm{Na}_{\text {Linmiao }}^{\mathrm{b}}$ & 8.40 & 11.67 & 35.72 & 56.78 & 14.92 & 79.67 & 4.07 & 1.00 & 0.01 \\
\hline $\mathrm{C} 7$ & Chang Sheng ${ }^{\mathrm{b}}$ & 3.56 & 8.09 & 36.46 & 58.40 & 14.51 & 79.35 & 4.87 & 1.04 & 0.02 \\
\hline $\mathrm{C} 8$ & Ding Jiaqu ${ }^{\mathrm{b}}$ & 2.86 & 5.04 & 35.32 & 61.42 & 13.45 & 80.65 & 4.49 & 1.04 & 0.00 \\
\hline C9 & Ha Lagou $^{\mathrm{b}}$ & 5.78 & 4.49 & 34.36 & 62.69 & 13.63 & 80.41 & 4.47 & 0.84 & 0.00 \\
\hline $\mathrm{C} 10$ & Hai Hong ${ }^{\mathrm{b}}$ & 4.55 & 4.32 & 32.55 & 64.54 & 12.66 & 81.56 & 4.62 & 1.00 & 0.00 \\
\hline $\mathrm{C} 11$ & Shang Wan ${ }^{\mathrm{b}}$ & 1.42 & 36.99 & 32.95 & 42.25 & 14.78 & 78.61 & 4.99 & 0.79 & 0.02 \\
\hline $\mathrm{C} 12$ & Zhang Gou & 0.73 & 12.33 & 8.12 & 80.55 & 3.86 & 91.21 & 3.38 & 1.25 & 0.15 \\
\hline $\mathrm{C} 13$ & Long $\mathrm{Gu}^{\mathrm{b}}$ & 1.06 & 17.10 & 35.84 & 53.18 & 7.78 & 84.39 & 5.32 & 1.63 & 0.01 \\
\hline $\mathrm{C} 14$ & Dong $\operatorname{Tan}^{\mathrm{b}}$ & 2.36 & 9.48 & 38.00 & 56.12 & 10.66 & 82.15 & 5.17 & 1.57 & 0.01 \\
\hline $\mathrm{C} 15$ & Liu $\mathrm{He}^{\mathrm{b}}$ & 0.85 & 12.24 & 12.40 & 76.87 & 3.87 & 90.47 & 3.85 & 1.21 & 0.01 \\
\hline $\mathrm{C} 16$ & Qi Shan ${ }^{b}$ & 2.14 & 30.17 & 40.12 & 41.81 & 12.76 & 79.51 & 5.36 & 1.79 & 0.01 \\
\hline $\mathrm{C} 17$ & Qi Shan*b & 1.98 & 31.64 & 35.79 & 43.90 & 11.98 & 80.79 & 5.31 & 1.40 & 0.01 \\
\hline $\mathrm{C} 18$ & Quan Tai ${ }^{\mathrm{b}}$ & 2.96 & 16.18 & 40.32 & 50.02 & 12.91 & 78.49 & 5.14 & 1.67 & 0.01 \\
\hline C19 & Ding $\mathrm{Ji}^{\mathrm{a}}$ & 1.24 & 38.02 & 40.65 & 36.79 & 13.90 & 78.71 & 5.52 & 1.40 & 0.01 \\
\hline $\mathrm{C} 20$ & Zhang Shuanglou ${ }^{\mathrm{b}}$ & 2.21 & 19.65 & 36.01 & 51.42 & 10.07 & 82.59 & 4.99 & 1.43 & 0.01 \\
\hline $\mathrm{C} 21$ & Kong Zhuang ${ }^{\mathrm{b}}$ & 2.58 & 20.39 & 36.36 & 50.67 & 8.26 & 83.42 & 5.11 & 1.43 & 0.01 \\
\hline $\mathrm{C} 22$ & Zhang $\mathrm{Ji}^{\mathrm{b}}$ & 1.70 & 30.07 & 39.18 & 42.53 & 12.66 & 80.36 & 5.02 & 1.34 & 0.02 \\
\hline $\mathrm{C} 23$ & Ke Lang ${ }^{\mathrm{a}}$ & 9.97 & 15.46 & 56.34 & 33.23 & 20.31 & 68.89 & 5.16 & 1.59 & 0.01 \\
\hline $\mathrm{C} 24$ & Gong Qing ${ }^{\mathrm{b}}$ & 0.69 & 10.85 & 22.64 & 68.49 & 3.40 & 89.90 & 4.77 & 1.68 & 0.01 \\
\hline $\mathrm{C} 25$ & Gong Qing ${ }^{* b}$ & 0.75 & 19.81 & 20.48 & 63.29 & 3.22 & 89.55 & 4.59 & 1.71 & 0.02 \\
\hline $\mathrm{C} 26$ & Xing Ying ${ }^{\mathrm{b}}$ & 0.62 & 14.04 & 19.96 & 68.38 & 4.19 & 89.25 & 4.46 & 1.64 & 0.02 \\
\hline $\mathrm{C} 27$ & Mao Ergou ${ }^{c}$ & 1.20 & 29.24 & 12.66 & 61.06 & 2.94 & 88.39 & 3.75 & 0.92 & 0.01 \\
\hline $\mathrm{C} 28$ & Chang Sheng $^{\mathrm{c}}$ & 0.61 & 4.71 & 5.67 & 89.34 & 1.27 & 94.09 & 3.04 & 0.77 & 0.01 \\
\hline C29 & Xu Jiayuan ${ }^{\mathrm{c}}$ & 0.47 & 9.47 & 7.00 & 83.79 & 1.15 & 93.02 & 3.30 & 0.85 & 0.00 \\
\hline
\end{tabular}

${ }^{a}$ Lignite

${ }^{\mathrm{b}}$ Bituminous Coal

${ }^{\mathrm{c}}$ Anthracite

${ }^{*}$ Sample collected from different coal seams at the same coal mine

are interconnected by aliphatic hydrocarbons, and lowmolecular-weight PAHs that exist as solids and liquids in coal [31]. PAH concentrations are affected by several factors, such as carbon content, volatile matter, $\mathrm{H} / \mathrm{C}$ mole ratio, and $\mathrm{O} / \mathrm{C}$ mole ratio, but the degree of their influence cannot be determined in the present study [3132]. Furthermore, current research on PAHs are mainly focused on the release of PAHs during combustion and pyrolysis of fossil fuels and thus knowledge on the occurrence and migration PAHs and environmental hazards from free PAHs in raw coal remains limited [33-34]. As groundwater levels rise quickly after the mine drainage systems of closed mines stop their operations, the free PAHs in the protective coal pillars 
and remaining coal seams of these mines are released into the groundwater, thereby polluting aquifers with mine water through mining-induced fractures, faults, and poorly sealed drill holes. Therefore, in order to guide mine closures, we investigated the levels and distributions of PAHs in coal mines in China. We then identified the correlation between PAHs and the physical and chemical properties of coal and analyzed the extent of contribution of different influencing factors on PAH content.

\section{Materials and Methods}

\section{Study Area and Sampling}

China has 14 coal bases. The most notable of these bases are located in the Shendong region, southwestern region of Shandong, Huaibei-Huainan region, and East Inner Mongolia-Northeast region. The main coal-forming periods are Carboniferous, Permian, Jurassic, Cretaceous, and Tertiary. In this study, a total of 29 samples were collected from different coal bases. The sampling distribution is shown in Fig. 1. In each sample site, approximately $1.5 \mathrm{~kg}$ coal sample was collected and placed into a sealed bag and then brought to the laboratory. A few of the collected samples were stored in brown glass bottle at $4{ }^{\circ} \mathrm{C}$ and used for $\mathrm{PAH}$ detection in the University of Science and Technology of China, and the remaining part was used for coal analysis in the Jiangsu Institute of Geology and Mineral Resources. All brown glass bottles were pre-combusted at $450^{\circ} \mathrm{C}$ for $4 \mathrm{~h}$ in order to remove the organic matter.

\section{Coal Analysis}

Coal analysis of coal samples were performed on the basis of Proximate Analysis of Coal (GB/ T212-2008) in the Jiangsu Institute of Geology and Mineral Resources. Table 1 shows the coal analysis data of 29 mines, including 5 lignite, 20 bituminous coal, and 4 anthracite. The results indicated that ash concentrations in the analyzed coal samples fall in the range of $4.32-38.02 \%$ with a mean of $16.10 \pm 9.93 \%$. The volatile content of raw coal varied from $5.67 \%$ to $56.34 \%$ with a mean of $31.29 \pm 12.51 \%$. The mole ratio of $\mathrm{H} / \mathrm{C}$ and $\mathrm{O} / \mathrm{C}$ varied from 0.388 to 0.899 and from 0.009 to 0.235 , respectively, among all the samples.

\section{PAH Analysis}

For the analysis of polycyclic aromatic hydrocarbon content in coal, samples were pretreated through the microwave-assisted solvent extraction method (MASE) described by Yuan [35]. NaP- $d_{8}$, Chry-d $\mathrm{d}_{12}$, and $\mathrm{Ph}-\mathrm{d}_{10}$ were added to $20 \mathrm{~g}$ of coal samples. Dichloromethane $(240 \mathrm{~mL})$ was then added to the mixture. The crude extract, collected by Soxhlet extractionm, was concentrated to about $2 \mathrm{~mL}$ in a rotary evaporator. After adding $10 \mathrm{~mL}$ of exchange solvent (n-hexane), the mixed decoction was concentrated to about $2 \mathrm{~mL}$. The polycyclic aromatic hydrocarbons in the extract were purified with an adsorption column containing silica and alumina gel $(2: 1)$ as adsorbents. Subsequently, the PAHs were leached from the column with $70 \mathrm{~mL}$ of hexane and dichloromethane (7:3) at a flow rate of $1 \mathrm{~mL} / \mathrm{min}$. The eluant was concentrated to $1 \mathrm{~mL}$, and then introduced into thermo trace ultra gas chromatography coupled with a Thermo DSQ II mass spectrometer (GC-MS) for PAH analysis. A $60 \mathrm{~m} \mathrm{x} 0.25 \mathrm{~mm}$ (L x ID) DB5 capillary column with a $0.25 \mu \mathrm{m}$-thick film was used. Helium was used as carrier gas at a flow rate of $1 \mathrm{~mL} / \mathrm{min}$. The injected sample volume was $1 \mu \mathrm{L}$ in splitless injection mode. The initial temperature of the capillary column was set at $50^{\circ} \mathrm{C}$ for $2 \mathrm{~min}$. The dynamic temperature program used was as follows: $60-200^{\circ} \mathrm{C}$ at $5^{\circ} \mathrm{C} / \mathrm{min}, 200-250^{\circ} \mathrm{C}$ at $2^{\circ} \mathrm{C} / \mathrm{min}, 250-290^{\circ} \mathrm{C}$ at $20^{\circ} \mathrm{C} / \mathrm{min}$, and then held at $290^{\circ} \mathrm{C}$ for $20 \mathrm{~min}$. The electron impact mode was $70 \mathrm{eV}$, and the mass spectra were recorded with selected ion-monitoring modes. Individual $\mathrm{PAH}$ concentrations in coal samples were calculated from a six-point calibration curve of standard solutions.

\section{Quality Control of Test Results}

The quality assurance and quality control procedures for the sample analysis were recommended by the United States Environmental Protection Agency (EPA). Method blanks, spiked blanks, and sample duplicates were performed during analysis. In the method blank samples there are no detections of the PAHs. The rate of recovery of 16-PAHs in NIST reference samples (National Institute of Standards and Technology, 1941) ranged from $76 \%$ to $105 \%$. Furthermore, individual PAH recoveries evaluated by standard solutions of $\mathrm{NaP}-\mathrm{d}_{8}$, Chry- $\mathrm{d}_{12}$, and Ph- $\mathrm{d}_{10}$ were $81.5 \% \pm 8.3 \%, 88.5 \% \pm 9.6 \%$, and $91.7 \% \pm 9.0 \%$, respectively. The detection limit of the instrument for PAH analysis ranged from $0.04 \mathrm{ng} / \mathrm{g}$ to $0.51 \mathrm{ng} / \mathrm{g}$.

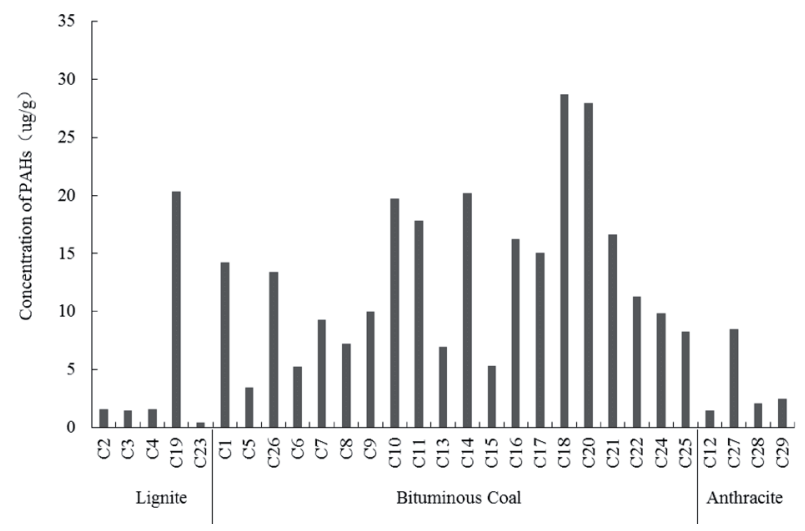

Fig. 2. Concentrations of 16-PAHs in coals from various coal mines in China. 
Table 2. PAH concentrations $(\mu \mathrm{g} / \mathrm{g})$ in different samples of raw coal.

\begin{tabular}{|c|c|c|c|c|c|c|c|c|c|c|c|c|}
\hline \multirow{2}{*}{ PAH } & \multicolumn{4}{|c|}{ Ligite $(n=5)$} & \multicolumn{4}{|c|}{ Bituminous Coal $(\mathrm{n}=20)$} & \multicolumn{4}{|c|}{ Anthracite $(n=4)$} \\
\hline & Min. & Max. & Mean & SD & Min. & Max. & Mean & SD & Min. & Max. & Mean & SD \\
\hline Nap & 0.046 & 3.675 & 0.803 & 1.606 & 0.043 & 4.962 & 1.286 & 1.407 & 0.175 & 0.970 & 0.431 & 0.363 \\
\hline Acy & $\mathrm{ND}^{\mathrm{a}}$ & 0.027 & 0.023 & 0.005 & ND & 0.708 & 0.103 & 0.182 & 0.000 & 0.013 & 0.009 & 0.006 \\
\hline Ace & 0.009 & 0.578 & 0.138 & 0.247 & 0.022 & 2.326 & 0.471 & 0.611 & 0.036 & 0.202 & 0.089 & 0.078 \\
\hline Fle & 0.031 & 3.535 & 0.739 & 1.563 & 0.077 & 4.501 & 1.271 & 1.489 & 0.131 & 0.483 & 0.240 & 0.166 \\
\hline Phe & 0.061 & 4.136 & 0.901 & 1.809 & 0.100 & 6.244 & 2.285 & 1.973 & 0.417 & 0.696 & 0.589 & 0.120 \\
\hline Anth & 0.018 & 0.499 & 0.126 & 0.209 & ND & 1.380 & 0.574 & 0.424 & 0.018 & 0.041 & 0.026 & 0.011 \\
\hline Fla & 0.039 & 0.976 & 0.286 & 0.391 & 0.106 & 2.622 & 0.951 & 0.772 & 0.030 & 0.287 & 0.107 & 0.120 \\
\hline Pyr & 0.043 & 2.048 & 0.485 & 0.875 & ND & 2.627 & 0.852 & 0.753 & 0.042 & 0.234 & 0.109 & 0.085 \\
\hline $\mathrm{BaA}$ & 0.021 & 1.537 & 0.449 & 0.625 & ND & 3.661 & 1.081 & 0.995 & 0.022 & 0.069 & 0.035 & 0.023 \\
\hline Chr & 0.021 & 1.292 & 0.356 & 0.539 & 0.347 & 2.570 & 0.959 & 0.540 & 0.066 & 1.117 & 0.445 & 0.467 \\
\hline $\mathrm{BbF}$ & 0.012 & 0.193 & 0.088 & 0.073 & ND & 4.026 & 0.978 & 1.117 & 0.029 & 1.691 & 0.591 & 0.747 \\
\hline $\mathrm{BkF}$ & 0.010 & 0.866 & 0.247 & 0.352 & 0.023 & 6.598 & 0.960 & 1.818 & 0.020 & 0.038 & 0.025 & 0.008 \\
\hline $\mathrm{BaP}$ & ND & 0.769 & 0.264 & 0.342 & ND & 1.829 & 0.487 & 0.516 & 0.015 & 0.086 & 0.036 & 0.033 \\
\hline Ind & ND & 0.412 & 0.200 & 0.184 & ND & 2.822 & 0.571 & 0.807 & 0.017 & 0.085 & 0.046 & 0.029 \\
\hline $\mathrm{DaA}$ & ND & 0.203 & 0.093 & 0.089 & ND & 2.877 & 0.439 & 0.636 & 0.015 & 1.357 & 0.379 & 0.653 \\
\hline $\mathrm{BgP}$ & ND & 0.037 & 0.020 & 0.012 & ND & 3.942 & 0.702 & 0.952 & 0.035 & 1.307 & 0.409 & 0.601 \\
\hline$\sum$ PAHs & 0.388 & 20.324 & 5.053 & 8.551 & 3.402 & 28.664 & 13.307 & 7.100 & 1.403 & 8.397 & 3.567 & 3.249 \\
\hline
\end{tabular}

${ }^{\mathrm{a}} \mathrm{ND}$ is not detection

\section{Results and Discussion}

\section{Levels of PAHs in Coal Mines}

The concentrations of the 16 PAHs - including naphthalene (Nap), acenaphthylene (Acy), acenaphthene (Ace), fluorene (Fle), phenanthrene (Phe), anthracene(Anth), fluoranthene (Fla), pyrene (Pyr), benzo[a]anthracene $(\mathrm{BaA})$, chrysene $(\mathrm{Chr})$, benzo[b] fluoranthene $(\mathrm{BbF})$, benzo[k]fluoranthene $(\mathrm{BkF})$,



Fig. 3. Occurrence characteristics of PAHs in different coals. benzo[a]pyrene (BaP), indeno[1,2,3-c,d]pyrene (Ind), dibenz[a,h]anthracene $(\mathrm{DaA})$, and benzo[g,h,i]perylene $(\mathrm{BgP})$ - in the coal samples are shown in Fig. 2, and the heights of the bars represent PAH content in the corresponding sample point. As shown in the figure, from lignite to anthracite, with the increase of coalification degree, the total PAH content (2-6 rings) changed along a quadratic curve. The total PAH concentrations in the coal ranged from $0.388 \mu \mathrm{g} / \mathrm{g}$ (C23, Kelang Coal Mine) to $28.664 \mu \mathrm{g} / \mathrm{g}$ (C18, Quantai Coal Mine) with a mean of $10.540 \pm 7.973 \mu \mathrm{g} / \mathrm{g}$. These obtained concentrations were consistent with those of naturally formed PAHs in the complex coal-forming process [36].

The monitoring results of PAHs in various coals is presented in Table 2. The concentrations of the 16 PAHs in the lignite, bituminous coal, and anthracite were $5.053 \pm 8.551, \quad 13.307 \pm 7.100$, and $3.567 \pm 3.249$ $\mu \mathrm{g} / \mathrm{g}$, respectively. The highest PAH concentration was observed in the bituminous coal. The observed distribution characteristics are attributed to the complex coal metamorphism during coal formation and monitored PAH types. Organic matter in lignite was dominated by chain hydrocarbon, and PAH concentrations in lignite were low. Meanwhile, at intensified coalification, some aliphatic hydrocarbons in raw coal were transformed into aromatic compound through dehydrogenation and cyclization. The concentrations and kinds of 
Table 3. Occurrence characteristics of PAHs in coal collected from other mines in the world.

\begin{tabular}{|c|c|c|c|c|c|c|c|}
\hline Country & Coal & Samples & $\sum$ PAHs & $\begin{array}{c}\text { LMW-PAHs } \\
(\%)\end{array}$ & $\begin{array}{c}\text { MMW-PAHs } \\
(\%)\end{array}$ & $\begin{array}{c}\text { HMW-PAHs } \\
(\%)\end{array}$ & Reference \\
\hline India & $\begin{array}{l}\text { Butumious } \\
\text { Coal }\end{array}$ & 1 & 4.542 & 7.3 & 28.3 & 64.4 & $\begin{array}{c}\text { Verma et al. } \\
\text { [32] }\end{array}$ \\
\hline \multirow{3}{*}{$\begin{array}{l}\text { United } \\
\text { States }\end{array}$} & Lignite & 7 & 1.049 & 17.8 & 59.0 & 23.2 & \multirow{3}{*}{$\begin{array}{c}\text { Stout et al. } \\
{[36]}\end{array}$} \\
\hline & $\begin{array}{c}\text { Butumious } \\
\text { Coal }\end{array}$ & 6 & 5.660 & 74.6 & 19.4 & 6.0 & \\
\hline & Anthracite & 2 & 1.064 & 63.4 & 19.7 & 16.9 & \\
\hline \multirow{2}{*}{$\begin{array}{l}\text { United } \\
\text { States }\end{array}$} & $\begin{array}{c}\text { Butumious } \\
\text { Coal }\end{array}$ & 3 & 17.773 & 29.8 & 34.8 & 35.4 & \multirow{2}{*}{$\begin{array}{c}\text { Wang et al. } \\
\text { [39] }\end{array}$} \\
\hline & Anthracite & 3 & 3.257 & 58.8 & 25.8 & 15.4 & \\
\hline
\end{tabular}

PAHs in the bituminous coal increased continuously. However, concentrations of the 16 PAHs in anthracite decreased because of the reduction of extractable PAHs.

In order to assess the distribution of PAH homologue in different coal types, the 16-PAHs are divided into three groups according to their molecular weight, i.e. low-molecular-weight PAHs (LMW-PAHs: Nap, Acy, Ace, Fle, Phe, and Anth), medium-molecular-weight PAHs (MMW-PAHs: Fla, Pyr, BaA, and Chr), and high-molecular-weight PAHs (HMW-PAHs: BbF, $\mathrm{BkF}$, BaP, Ind, DaA, and $\mathrm{BgP}$ ) [37]. The average concentrations of LMW-PAHs (2-3 ring PAHs) were highest, which constituted $44 \%$ of the $16-\mathrm{PAH}$ content, followed by MMW-PAHs (29\%) and then HMW-PAHs (27\%). Fig. 3 shows the occurrence characteristics of different rings of PAHs in raw coal. The results showed that the concentration of LMW-PAHs in lignite, bituminous coal, and anthracite were $35 \%, 45 \%$, and $52 \%$, respectively. In contrast, with the increase of coalification the percentage of MMW-PAHs decreases from $37 \%$ to $18 \%$. PAH concentrations in raw coal in other countries are listed in Table 3. To compare with previous research, similar patterns were also found in coal in India and the United States, although the ratio is different. This may have been caused by the different coal origins of different countries [38].

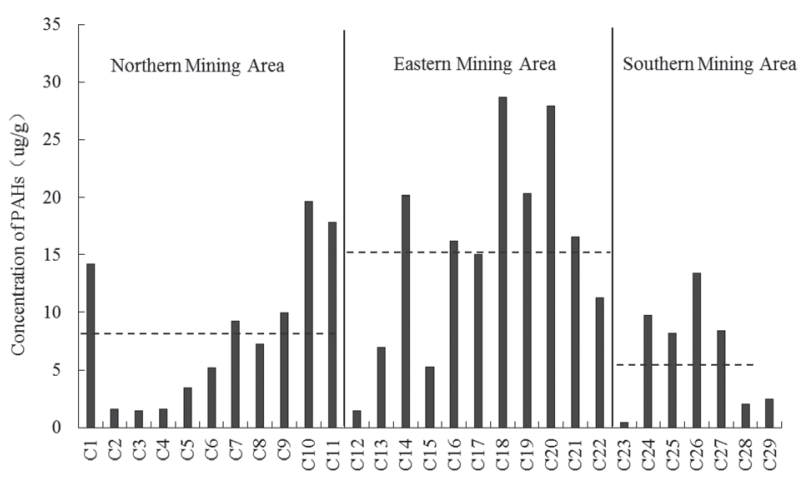

Fig. 4. Regional distribution of PAHs in Chinese raw coal.

\section{Regional Distribution of PAHs in Chinese Coal}

In China, the regional distribution of PAHs showed distinct regional characteristics (Fig. 4). On the basis of different coal-forming eras, all coal mines were divided into three regions. As shown in the picture, coal distribution had significant regional characteristics, and the concentrations of 16 PAHs varied among different coal mining areas. The concentrations of the 16 PAHs in raw coal from China's eastern mining areas were significantly higher than those from other mining areas. The raw coal from Quantai Coal Mine (C18) contained the highest PAH concentration (28.66 $\mu \mathrm{g} / \mathrm{g})$, followed by Zhangshuanglou Coal Mine (C20). The enrichment of PAHs in China's eastern mining may be associated with the geological environment and the evolvement process of coal. The data analysis results revealed that most coal resources in the eastern coal mining areas were comprised of bituminous coal, therefore the concentrations of 16 PAHs were relatively high. By contrast, the major coal in northern and southern mining areas of China is lignite and anthracite, and the concentrations of PAHs in raw coals were low.

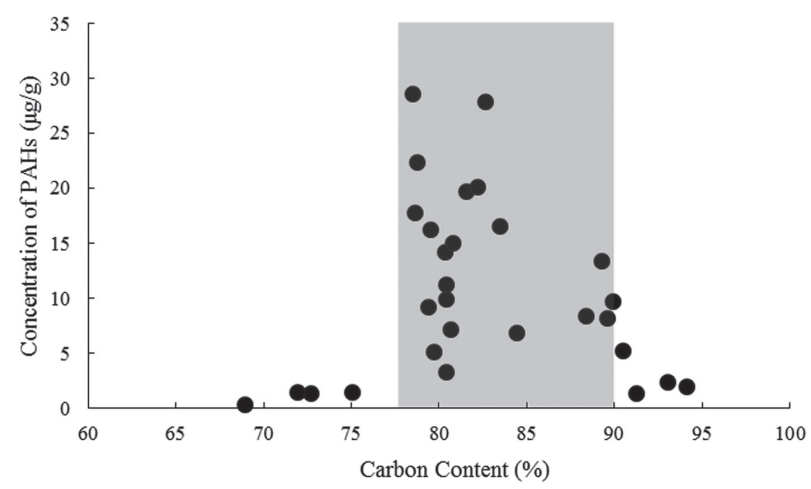

Fig. 5. Relationship between 16-PAHs and carbon content. 


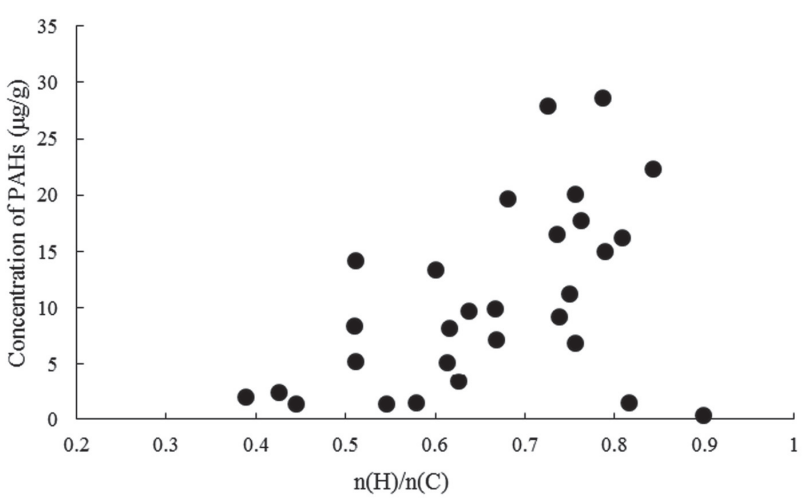

Fig. 6. Relationship between 16-PAHs and H/C molar ratio.

\section{Influencing Factors of PAH Distribution}

It has been reported that the concentrations of 16 PAHs were influenced by the physicochemical properties of raw coal, including carbon content, volatile matter, $\mathrm{H} / \mathrm{C}$, and $\mathrm{O} / \mathrm{C}$ [39-40]. The relationship between the 16 PAHs in the coal samples and carbon content is shown in Fig. 5. The result showed that PAH concentration increased gradually first and then sharply when carbon content increased from $70 \%$ to $82 \%$. This increase may be attributed to coalification in which some PAHs formed through condensation reactions of

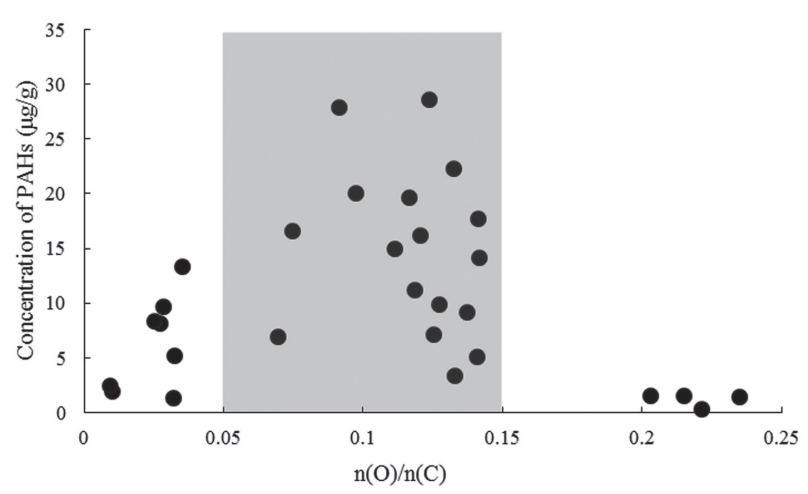

Fig. 7. Relationship between 16-PAHs and O/C molar ratio.

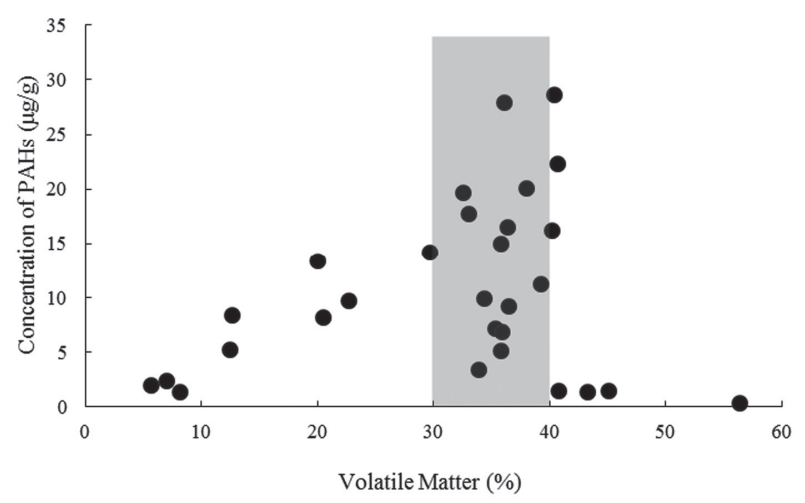

Fig. 8. Relationship between 16-PAHs and volatile component. aliphatic hydrocarbons containing oxygen and sulfur groups. Therefore, the concentration and ring number of PAHs increased at increased carbon content in the course of coalification. After the carbon content reached $84 \%$, some PAHs with high molecular weights became difficult to extract in the experiment, thus decreasing the concentrations of 16 PAHs. The amounts of the 16 PAHs extracted from the raw coals considerably increased at carbon contents ranging from $78 \%$ to $90 \%$.

The molar ratio of $\mathrm{H} / \mathrm{C}$ is one of the most important parameters of coalification degree. On the basis of the structural changes in the organic matter of coal, a low $\mathrm{H} / \mathrm{C}$ ratio indicates a high degree of cyclization in coal structure, and a substantial amount of PAH is detected in raw coal. As shown in Fig. 6, the concentrations of the PAHs were associated with the molar ratio of $\mathrm{H} / \mathrm{C}$. At decreased molar ratio of $\mathrm{H} / \mathrm{C}$, the concentrations of the 16 PAHs increased slowly at the beginning, and then rapidly increased, and finally decreased after reaching a peak value. A substantial amount of PAHs were extracted from the raw coal samples with $\mathrm{H} / \mathrm{C}$ molar ratios of around 0.75 . This result was observed in the coal samples from Zhangshuanglou Coal Mine (C20) and Quantai Coal Mine (C18). In contrast to the trend in Fig. 5, the trend in the changes in the $\mathrm{H} / \mathrm{C}$ molar ratios of the 16 PAHs were similar to the laws of PAHs with carbon content.

Similarly, a substantial amount of PAH was detected at $\mathrm{O} / \mathrm{C}$ molar ratio of $0.05-0.15$, and the maximum value was obtained at $\mathrm{O} / \mathrm{C}$ molar ratio of around 0.11 . The element oxygen usually exists in aliphatic hydrocarbons, and the higher the $\mathrm{O} / \mathrm{C}$ molar ratio, the lower the amount of aromatic compounds in raw coal. During the evolution of the coal, the oxygen was constantly separated through oxidative dehydrogenation. Therefore, at a low $\mathrm{O} / \mathrm{C}$ molar ratio, the aromatic compounds are the main compositions of organic compounds in the coal samples.

The 16-PAHs are part of a volatile component of raw coal, and the relationships between them are inevitably produced (Fig. 8). The volatile component in raw coal, referred to volatile organic matter and readily decomposable mineral, is an important indicator of the degree of coalification. As shown in Fig. 8, PAH concentrations are high at volatile component of

Table 4. Relative contribution of different factors on PAH content in coal.

\begin{tabular}{|c|c|c|c|c|}
\hline $\begin{array}{c}\text { Influence } \\
\text { Factor }\end{array}$ & $\mathrm{A}$ & $\mathrm{B}$ & $\mathrm{C}=\mathrm{A} * \mathrm{~B}$ & $\begin{array}{c}\text { Relative } \\
\text { Contribution } \\
(\%)\end{array}$ \\
\hline Carbon content & -0.752 & -0.052 & 0.039 & 10.77 \\
\hline Volatile matter & 0.490 & 0.229 & 0.112 & 30.94 \\
\hline $\mathrm{H} / \mathrm{C}$ & 0.242 & 0.460 & 0.111 & 30.66 \\
\hline $\mathrm{O} / \mathrm{C}$ & -1.351 & -0.074 & 0.100 & 27.63 \\
\hline
\end{tabular}


$30-40 \%$. A high volatile component content indicates the presence of more aliphatic hydrocarbons in raw coal (Lignite). In contrast, most organic compounds exist as macromolecules in anthracite with low content of volatile component and thus are difficult to extract.

\section{Analysis of Contributions of Different Influencing Factors}

The above analysis shows that carbon content, volatile matter, $\mathrm{H} / \mathrm{C}$, and $\mathrm{O} / \mathrm{C}$ are related to the content of 16-PAHs in raw coal. The relative contribution of the four factors to PAH content was analyzed through convergence analysis performed in Eviews 6.0 [41]. As illustrated in Table 4, parameter A refers to multiple linear regression standard coefficients under different influence factors, and parameter B is linear regression standard coefficients among different factors and among the 16 PAHs. The relative contribution is the ratio of single influence (parameter $\mathrm{C}$ ), the product of parameter $\mathrm{A}$ and parameter $\mathrm{B}$, to total influence. The calculated result indicated that the volatile matter and molar ratio of $\mathrm{H} / \mathrm{C}$ had a positive effect on $\mathrm{PAH}$ concentrations in raw coal, and the influence is highly evident. The relative contribution of volatile matter was the highest, accounting for $30.94 \%$, followed by $\mathrm{H} / \mathrm{C}$ molar ratio, which accounts for $30.66 \%$. Overall, the volatile matter and molar ratio of $\mathrm{H} / \mathrm{C}$ plays a leading role in the changes in the PAHs, and the total proportion was over $60 \%$. Our results were found to be consistent with the previous studies. Wang (2010) analyzed the effect of carbon content, $\mathrm{H} / \mathrm{C}$, and $\mathrm{O} / \mathrm{C}$ on $16-\mathrm{PAHs}$ content in Chinese and American coal, and the relationships were fitted by Gauss-fit. The result showed that the effect of $\mathrm{H} / \mathrm{C}$ on PAHs content was clearly greater than carbon content and $\mathrm{O} / \mathrm{C}$ [39]. This result may be due to the changes in the chemical structures of organic compounds during coal metamorphism and evolution process. Coal evolution is a continuous process of aliphatic hydrocarbon condensation. In this process, the volatile matter continues to decline during the separation of $\mathrm{O}$ elements, and the molar ratio of $\mathrm{H} / \mathrm{C}$ continues to grow. Accordingly, the volatile matter and molar ratio of $\mathrm{H} / \mathrm{C}$ can directly reflect the changes in PAHs in raw coal.

\section{Conclusions}

Twenty-nine coal samples were collected from different coal bases to analyze the distributions of polycyclic aromatic hydrocarbons in coal and the factors influencing these distributions. The total concentration of PAHs (mean value) was $10.540 \pm 7.973 \mu \mathrm{g} / \mathrm{g}$. In this concentration, LMW-PAHs had the highest concentrations, constituting 44\% of average share in the PAHs. Overall, the highest concentrations of extractable PAHs were detected in bituminous coals, followed by the concentrations in lignite. The lowest concentration was obtained in anthracite. The concentrations and kinds of PAHs in bituminous coal increased continuously. Furthermore, the influences of carbon content, volatile matter, $\mathrm{H} / \mathrm{C}$, and $\mathrm{O} / \mathrm{C}$ on $\mathrm{PAH}$ content in raw coals are significant. The volatile matter and molar ratio of $\mathrm{H} / \mathrm{C}$ play a leading role in the changing process in the PAHs, accounting for more than $60 \%$ of the total contribution, followed by the molar ratio of $\mathrm{O} / \mathrm{C}$ and carbon content.

\section{Acknowledgements}

This research is supported by the National Natural Science Foundation of China: Degradation and Migration of Polycyclic Aromatic Hydrocarbons (PAHs) in Groundwater at Abandoned Coalmines (No. 41472223), and the Research and Innovation Project for College Graduates of Jiangsu Province (No. KYLX15_1439).

\section{Conflict of Interest}

The authors declare no conflict of interest.

\section{References}

1. HU W.Y., YAN L.Y. Characteristics of Groundwater Pollution in Abandon Coal Mine and Control Technique. Coal Mine Environmental Protection, 4, 37, 2000.

2. ZHOU J.W., ZHANG Q.X., KANG F.X., ZHANG Y.P., YUAN L., WEI D., LIN S.H. Using multi-isotopes $\left({ }^{34} \mathrm{~S}\right.$, $\left.{ }^{18} \mathrm{O},{ }^{2} \mathrm{H}\right)$ to track local contamination of the groundwater from Hongshan-Zhaili abandoned coal mine, Zibo city, Shandong province. International Biodeterioration \& Biodegradatio, 1, 2016.

3. DUAN G.W., LIANG Y.P. Analysis of sulphate pollution in Karst Groundwater in Yangquan by ${ }^{34} \mathrm{~S}$. West-China Exploration Engineering, 117, 100, 2006.

4. LI T., FENG Q.Y., QIAN B., ZHOU L., GAO B. Chemical characteristics of coal mine drainage and its impact on the environment in Shandong province, China. Journal of Chemical and Pharmaceutical Research, 5, 146, 2013.

5. MONCUR M.C., PTACEK C.J., HAYASHI M., BLOWES D.W., BIRKS S.J. Seasonal cycling and mass-loading of dissolved metals and sulfate discharging from an abandoned mine site in northern Canada. Applied Geochemistry, 41, 176, 2014.

6. CHEN L., FENG Q.Y., GAO B., ZHOU L., MENG Q.J. The Health Risk Assessment of Organic Pollution in Coal Mine Water. Industrial Safety and Environmental Protection, 41, 21, 2015.

7. BELL F.G., BULLOCK S.E.T., HÄLBICH T.F.J., LINDSAY P. Environmental impacts associated with an abandoned mine in the Witbank Coalfield, South Africa. International Journal of Coal Geology, 45, 19, 2001.

8. SPEIGHT J.G. The chemistry and technology of coal, second ed. Marcel Dekker, New York, 1994. 
9. LI H., CHEN J., JIANG L. Elevated critical micelle concentration in soil-water system and its implication on PAH removal and surfactant selecting. Environmental Earth Sciences, 71, 3991, 2014.

10. TAY C.K., BINEY C.A. Levels and sources of polycyclic aromatic hydrocarbons (PAHs) in selected irrigated urban agricultural soils in Accra, Ghana. Environmental Earth Sciences, 68, 1773, 2013.

11. YU Y., WANG Q., LI L., SUN P., ZHANG Y.P., LIN H.P., CHEN J.H., LIN B.G., XIANG M.D. The Variations of Concentrations, Profiles and Possible Sources of Metals and Polycyclic Aromatic Hydrocarbons in PM10 from Lanzhou, China. Polish Journal of Environmental Studies, 25, 1323, 2016 [In Polish].

12. LIU S.Q., WANG C.H., ZHANG S.J., LIANG J., CHEN F., ZHAO K. Formation and distribution of polycyclic aromatic hydrocarbons (PAHs) derived from coal seam combustion: A case study of the Ulanqab lignite from Inner Mongolia, northern China, s90, 126, 2012.

13. DING K.Q., LUO Y.M. Biodegradation of polycyclic aromatic hydrocarbons (PAHs) contaminated soil. Soil, 33, 169, 2001.

14. YAN Z.S., JIANG H.L., LI X.H., SHI Y. Accelerated removal of pyrene and benzo[a]pyrene in freshwater sediments with amendment of cyanobacteria-derived organic matter. Journal of Hazardous Materials, 272, 66, 2014.

15. WANG H., SUN L.N., LIU Z., WANG Y.G., LUO Q., CHEN S., WANG X.X., WU H. The Levels and Risks of Heavy Metals, Polycyclic Aromatic Hydrocarbons, and Polychlorinated Biphenyls in Hun River in Northeastern China. Polish Journal of Environmental Studies, 25, 2167, 2016 [In Polish].

16. BACOSA H., SUTO K., INOUE C. Preferential degradation of aromatic hydrocarbons in kerosene by a microbial consortium. International Biodeterioration \& Biodegradation, 64, 702, 2010.

17. LÓPEZ E., SCHUHMACHER M., DOMINGO J.L. Human health risks of petroleum-contaminated groundwater. Environmental Science \& Pollution Research, 15, 278, 2008.

18. LIU B., XUE Z.Q., ZHU X.L.,JIA C.R. Long-term trends (1990-2014), health risks, and sources of atmospheric polycyclic aromatic hydrocarbons (PAHs) in the U.S. Environmental Pollution, 220, 1171, 2016

19. YU X.L., ZHANG J. Pollution by multiring aromatic hydrocarbon and its preventive treatment strategy. Environmental Protection of Oil \& Gas Fields, 6, 53, 1996.

20. YANG M.M., WANG Y., LIU Q., DING A.J., LI Y.H. The Influence of Sandstorms and Long-Range Transport on Polycyclic Aromatic Hydrocarbons (PAHs) in PM2.5 in the High-Altitude Atmosphere of Southern China. Atmosphere, 6, 1633, 2015.

21. DUMANOGLU Y., GAGA E.O., GUNGORMUS E., SOFUOGLU S.C., ODABASI M. Spatial and seasonal variations, sources, air-soil exchange, and carcinogenic risk assessment for PAHs and PCBs in air and soil of Kutahya, Turkey, the province of thermal power plants. Science of the Total Environment, 580, 920, 2017.

22. GU X.Y., WU, J., WANG M., WU J.Q., XU Z.H., TANG H., SU J.H. Research advance of polycyclic aromatic hydrocarbons in environment: a bibliometric analysis based on Web of Science. Environmental Science\& Technology, 39, 196, 2016.
23. ODABASI M., DUMANOGLU Y., KARA M., ALTIOK H., ELBIR T., BAYRAM A. Spatial variation of PAHs and PCBs in coastal air, seawater, and sediments in a heavily industrialized region. Environmental Science \& Pollution Research, 78, 1, 2016.

24. LIU J.F., CHEN W.H. Remediation of phenanthrene contaminated soils by nonionic -anionic surfactant washing coupled with activated carbon adsorption. Water Science \& Technology, 72, 1552, 2015.

25. SHAO Y.X., WANG Y.X., WU X., XU X.Q., KONG S.Q., TONG L., JIANG Z., LI B. Biodegradation of PAHs by Acinetobacter, isolated from karst groundwater in a coalmining area. Environmental Earth Sciences, 73, 7479, 2015.

26. BACOSA H.P., SUTO K., INOUE C. Degradation potential and microbial community structure of heavy oil-enriched microbial consortia from mangrove sediments in Okinawa, Japan. Journal of Environmental Science and Health Part A-Toxic/Hazardous Substances \& Environmental Engineering, 48, 835, 2013.

27. BACOSA H.P, INOUE C. Polycyclic aromatic hydrocarbons (PAHs) biodegradation potential and diversity of microbial consortia enriched from tsunami sediments in Miyagi, Japan. Journal of Hazardous Materials, 238, 689, 2015.

28. ZHANG T., YANG W.L., CHEN S.J., SHI D.L., ZHAO H., DING Y., HUANG Y.R., LI N., REN Y., MAI B.X. Occurrence-sources and ecological risks of PBDEs-PCBsOCPs and PAHs in surface sediment of the Yangtze River Delta city cluster, China. Environmental Monitoring \& Assessment, 186, 5285, 2014

29. RAJPARA R.K., DUDHAGARA D.R., BHATT J.K., GOSAI H.B., DAVE B.P. Polycyclic aromatic hydrocarbons (PAHs) at the Gulf of Kutch, Gujarat, India: Occurrence, source apportionment, and toxicity of PAHs as an emerging issue. Marine Pollution Bulletin, 119, 231, 2017.

30. LARCHER T., PERRICHON P., VIGNET C., LEDEVIN M., MENACH K., LYPHOUT, L., LANDI L., CLERANDEAU C., LEBIHANIC F., MÉNARD D., BURGEOT T., BUDZINSKI H., AKCHA F., CACHOT J., COUSIN X. Chronic dietary exposure of zebrafish to PAH mixtures results in carcinogenic but not genotoxic effects. Environmental Science \& Pollution Research, 21, 13833, 2014.

31. ZHAO Z.B., LIU K.L., XIE W., PAN W.P., RILEY J.T. Soluble polycyclic aromatic hydrocarbons in raw coals. Journal of Hazardous Materials, 73, 77-85, 2000.

32. VERMA S.K., MASTO R.E., GAUTAM S., CHOUDHURY D.P., RAM L.C., MAITI S.K., MAITY S. Investigations on PAHs and trace elements in coal and its combustion residues from a power plant. Fuel, 162, 138, 2015.

33. QIN L., HAN J., HE X., LU Q. The emission characteristic of PAHs during coal combustion in a fluidized bed combustor. Energy Sources Part A Recovery Utilization \& Environmental Effects, 36, 212, 2014.

34. WANG Y., XU Y., CHEN Y., TIAN C., FENG Y., TIAN T., LI J., ZHANG G. Influence of different types of coals and stoves on the emissions of parent and oxygenated PAHs from residential coal combustion in China. Environmental Pollution, 212, 1, 2016.

35. YUAN Z.J., LIU G.J., DA C.N., WANG J., LIU H.Q. Occurrence, sources, and potential toxicity of polycyclic aromatic hydrocarbons in surface soils from the 
yellow river delta natural reserve, china. Archives of Environmental Contamination \& Toxicology, 68, 330, 2015.

36. STOUT S.A., EMSBO-MATTINGLY S.D. Concentration and character of PAHs and other hydrocarbons in coals of varying rank - Implications for environmental studies of soils and sediments containing particulate coal. Organic Geochemistry, 39, 801, 2008.

37. XUE J., LIU G.J., NIU Z.Y., CHOU C.L., QI C.C., ZHENG L.G., ZHANG H.Y. Factors That Influence the Extraction of Polycyclic Aromatic Hydrocarbons from Coal. Energy \& Fuels, 21, 881, 2007.

38. RADKE M., WILLSCH H., TEICHMÜLLER M. Generation and distribution of aromatic hydrocarbons in coals of low rank. Organic Geochemistry, 15, 539, 1990.
39. WANG R.W., LIU G.J., ZHANG J.M., CHOU C.L., LIU J.J. Abundances of Polycyclic Aromatic Hydrocarbons (PAHs) in 14 Chinese and American Coals and Their Relation to Coal Rank and Weathering. Energy \& Fuels, 24, 6061, 2010.

40. LIU S.Q., WANG Y.Y., ZHANG S.J., BAO P.C., DANG J.L. Distribution Features of Polycyclic Aromatic Hydrocarbons in Four Different Low Rank Coals, Coal Science and Technology, 38, 120, 2010.

41. PAPYRAKIS E., GERLAGH R. The resource curse hypothesis and its transmission channels. Journal of Comparative Economics, 32, 181, 2004. 